\title{
Transboundary Educational Reform of the Traditional Graphic Design Major under the Influence of AR Technology
}

\author{
Qiong Xie \\ University of Shanghai for Science and Technology \\ Shanghai, China 450006
}

\begin{abstract}
The modern graphic design education must keep pace with the times and embody the upgrading of business application. AR and VR technologies are leading-edge in the design field in recent years and the wind indicator of innovative design in the future. This paper discusses the meaning and method of applying AR technology to the graphic design education and explains how to better apply the AR technology to the graphic design education of universities. It is urgent to carry out the innovative reform of the traditional graphic design education, in which great opportunities exist. Feasible plans have been provided to promote the extensive application of $A R$ technology in the field of graphic design education.
\end{abstract}

Keywords-AR technology; graphic design; design education

\section{INTRODUCTION}

AR technology is also called the Augmented Reality technology, referring to the electronic virtual imaging technology on the basis of print media. Under the influence of digital media, we can see a new pattern of information spreading. 1 The audio-visual technology, digital technology and network technology brought by the digital media technology furthest meet people's requirements. The development of AR technology has broken the original fixed boundary. The art and design change from the original single mode to the systematic and integrated mode. The design works show a cross-border representation form. The traditional graphic design education under the popularization and development of AR technology is facing challenges and opportunities about how to apply the new educational pattern to the traditional graphic design major so as to establish the mechanism in training new type cross-media design talents.

\section{OPPORTUNITIES AND CHALLENGES FOR THE}

TRADITIONAL GRAPHIC DESIGN EDUCATION UNDER THE INFLUENCE OF THE AR TECHNOLOGY

After saying goodbye to the era with printed newspapers, periodicals and books, we have entered the media era of rapid information transfer full of electronic books, mobile phones and network to communicate and release news. In this "paperless" era of media transmission, in order to better guide students of design major to seize the opportunity in the change of times and improve the ability of design education, design educators need to have a comprehensive research and understanding.

\section{A. Opportunities for the Traditional Graphic Design Education under the Influence of AR Technology}

Under the impact of new media, the traditional print media loses some market shares, but it doesn't mean the disappearance of it. We not totally abandon the original contents of design education but research how to discuss the new educational pattern of cross-border design on the basis of the original media design education, researching through the combination of tradition and innovation. Specialized teachers can use the important method of "old elements new combination" of graphic creative design and train innovative cross-border talents through the application of AR technology. As the main media pusher to supplement the electronic technology, AR media technology can be used to improve the integral application of teaching resources, forming a new type educational pattern to combine the AR technology research, the paper media carrier research and the design basis reinforcement.

\section{B. Challenges for the Traditional Graphic Design Education under the Influence of AR Technology}

The appearance and the popularization of AR technology bring opportunities as well as challenges for the traditional graphic design education. Teachers and students need to change the point of view and regard it with dialectical thoughts.

1) New requirements for teachers:The most basic and necessary requirement for the teaching ability of teachers is to control and understand the new trend, grasp the technology and the changes of design methods. Under the new situation, teachers should also learn continuously and know about the market in advance.

2) New requirements for students: How to learn is important for students. Students are personalized, so it helps to improve their professional levels through finding proper learning methods and establishing a better model to communicate with professional teachers. 


\section{ESTABLISHMENT OF THE TALENT TRAINING MECHANISM}

The training of design talents in universities needs to closely combine with the requirement of society. The traditional graphic design major uses the talent training mechanism meeting the requirements of traditional media. Nowadays, with the fast-changing media, appropriate talent training mechanism must be established to train qualified design talents.

\section{A. Optimize the Course System and Consolidate the Basic Education}

The soul of design is the creativity. It is the true core value regardless of the technological development. It is distinctly important to integrate the ideas between design and other disciplines, reasonably and naturally teach students the basic disciplinary knowledge through basic courses of disciplines as well as integrate and optimize resources on the basis of AR design requirements, so as to train design talents with crossborder creative capability. Take the university where the author is in as an example, at the beginning of the entrance, students need comprehensive and systematic learning and improvement in painting and design; in the second year, students have to choose the major fields, including the research on the print media and the research on the new media design. In the class researching on the print media, we will provide some minor courses of cross-border design on the basis of printing, like the electronic publications design, cross-border design and web design, helping students to build the crossmedia design concept. Meanwhile, students must complete certain credits of the computer aided design course. In the third year, all assignments of the specialized course must be completed on the computer. Students must learn courses related to the dynamic design concept. Therefore, students improve the skills to operate the design software and let the knowledge reserve not confined to the single knowledge structure of graphic media design. Moreover, they can find interests and specialty features in learning different types of knowledge, expanding the spaces for the development and creation in the future.

\section{B. Strengthen the Practical Teaching and Establish All- Round Industry-University-Research Cooperation}

The discipline of graphic design not only teaches theoretical knowledge simply but also combines with the practice. 2 In teaching practice, it is necessary to optimize the specialized course system continuously, arrange the basic theory courses, the courses related to the innovation ability and the practice courses, as well as build the new teaching system, namely the basic theory plus the professional skill plus the courses related to the innovative design ability. For example, the course system of visual communication design in domestic renowned colleges of fine arts at present gradually forms the unique orientation, takes the theory course prior to the practice course and establishes the course system of the industryuniversity-research practice base in the summer intern, realizing the practice teaching model integrating the training resources in enterprises with the resources of laboratory in the school. Because of the defects of laboratory, practice bases in the enterprises are established for the training project. The production practice bases are established in enterprises of printing, multimedia and the most advanced Motion Magic Digital Entertainment Inc. researching AR and VR, in which students can learn how to combine the print media with the AR technology.

\section{The Construction of Cross-Media Laboratory and Comprehensive Laboratory}

Different cross-media laboratories are established in the college to help students to do experiment and research the design of different media. Laboratories of book design, packaging design, streaming media, spreading and interaction are also set up in the college. In these laboratories, students need to research the theoretical and practical knowledge required in the traditional graphic design as well as the application of the AR technology to the media. Teachers can integrate the resources of different laboratories and let students complete the comprehensive design. For example, in the classes of book design and packaging design, teachers ask students to complete the basic design of paper media like the book and packaging; in the class of cross-border design, students are required to apply the AR technology on the basis of the former two courses and finally complete the design of publications and external packing of AR technology. The design combining the paper media and the AR technology can be completed through the connection of functions of laboratory from the first to the second academic year.

\section{Hold and Participate in Competitions and Build the Communication Platform}

The organization of small arena contests in class and the participation of competitions at provincial and municipal level can be carried out to establish the good learning style among students. Teachers organize and lead the corresponding groups to participate in the competitions. The college provides necessary hardware and software resources and helps students to know about the level of related universities and the society.

\section{E. Pay Attention to the Innovation of Graduation Design}

The graduation design is one of the important parts of the teaching practice for students majored in the visual communication design. It is not only the summary and report of knowledge grasped by students in school but also the final assessment of their learning effects and quality. In the critical moment of employment and further study, the graduation design will be the final inspection of students' vocational ability and operative skills. The comprehensive ability of students in solving problems has been improved through the curriculum provision, expansion of comprehensive practical ability and the training in the first-class enterprises.

The topics for students majored in the traditional visual graphic design are single, like printing books, customary packing or web and UI design. With the development of AR technology, the AR technology on the mobile phone is set up on the basis of the ordinary book design to supplement the paper media, which improves the innovation of our graduation design. In the graduation design of the recent two years, some students have designed the packaging and book design with 
AR technology. The comprehensive subject research related to the cross-media helps students' improvement in the design industry and lays a solid foundation for their further study and employment.

\section{F. The Mechanism to Promote the Improvement of Teachers'} Teaching Level

In the teaching process, teachers of the specialized courses lead students to participate in some real projects, including the task in the graduation design. Teachers can guide students to complete the commercial projects to form the teaching model of project responsibility system, improving the professional level of teachers as well as providing a new channel for students to contact the society, in order to let the specialized teachers think about the classroom teaching model and improve the teaching contents actively.

\section{CONCLUSION}

In conclusion, with the soaring development of $\mathrm{AR}$ technology at present, the traditional graphic design major is facing opportunities and difficulties in the transformation. It is necessary for teachers to conclude and think continuously, refer to the domestic and overseas excellent methods and modes to explore a suitable road for the development of crossborder design in accordance with the specific circumstances of the school.

\section{REFERENCES}

[1] Enlightenment and Teaching Thinking Given by the Digital Media Technology for the Modern Graphic Design Education [J], Ye Jianhong, Drama Home, May 2011

[2] Analysis and Thinking on the Current Situation of Graphic Design Education [J], Liu Xiuwei, Li Jing. China Packaging Industry, August 2014 